\section{Temperature and Light Influence Growth and Flower Production in Heliconia 'Golden Torch'}

\author{
Jocelyn L. Catley and Ian R. Brooking \\ The Horticulture and Food Research Institute of New Zealand, Batchelar \\ Research Centre, Tennent Drive, Private Bag 11 030, Palmerston North, \\ New Zealand
}

Additional index words. Heliconia, photosynthetic photon flux, inflorescence

\begin{abstract}
Flowering responses of Heliconia psittacorum L.f. $x$ H. spathocircinata Aristeguieta 'Golden Torch' to temperature and photosynthetic photon flux (PPF) were determined in controlled-environment conditions using a $2 \times 2$ factorial combination of temperature (32C day/20C night and 24C day/20C night) and PPF $\left(475\right.$ and $\left.710 \mu \mathrm{mol} \cdot \mathrm{m}^{-2} \cdot \mathrm{s}^{-1}\right)$. Temperature had no significant effect on new shoot production, with an average of 9.3 shoots per plant being produced over the 248 days of treatment. More shoots, however, were produced at the higher PPF level (10.1 compared with 8.3 shoots). The proportion of shoots that initiated flowers $(\mathbf{8 5 \%})$ was similar in all treatments. The duration from shoot until inflorescence emergence was significantly less at $32 \mathrm{C}$ day/20C night than at $24 \mathrm{C}$ day/ 20C night (140 and 146 days, respectively) and was unaffected by PPF. This duration also was significantly affected by the interacting effects of order of shoot appearance and the number of leaves subtending the inflorescence. The second shoots to emerge had the shortest duration from shoot emergence to inflorescence emergence. The number of leaves subtending the inflorescence increased at the higher temperature and decreased as shoot order increased but was unaffected by PPF. Temperature and PPF levels influenced total leaf area at flowering, with highest areas being achieved in the high temperature-low PPF combination. Acceptable flower quality with at least two, opened, well-formed, wellcolored bracts was obtained in all treatments, although flower stems were taller and thicker at 32C day/20C night and these dimensions increased further with increasing order of shoot appearance. Stem diameters tended to be thinner at the lower PPF level. Overall, temperature was more dominant than light in influencing production and quality of flowers, but developmental factors associated with the order of shoot appearance also played a significant role. Flower production of 'Golden Torch' should be feasible in temperature-controlled glasshouses in temperate regions where mean air temperatures can be maintained at $\approx 20 \mathrm{C}$.
\end{abstract}

Heliconiapsittacorum $\times$ H. spathocircinata 'Golden Torch' (syn. 'Parrot' and 'Yellow Bird') (Berry and Kress, 1991) is a tropical herbaceous perennial with a branched rhizome system. Rhizomes develop from axillary buds at the base of the shoot. Each erect shoot bears a variable number of leaves and often a terminal inflorescence and is termed a "pseudostem." Heliconia is the only genus in the plant family Heliconiaceae, but it is a member of the larger orderZingiberales, which includes Musaceae, Zingiberacae, and Strelitziaceae. It is grown widely in parts of the American continent, the Caribbean, Europe, and Australia as a cut flower or a potted plant or is used in interior landscape design

Received for publication 1 June 1995. Accepted for publication 26 Sept. 1995. We thank Chrysalis Holdings, Waikanae, New Zealand, for supplying plant material; members of the New Zealand National Climate Laboratory Technical Services Group for maintenance of the controlled-environment rooms during this study; and H. Nihal de Silva for statistical analyses. The cost of publishing this paper was defrayed in part by the payment of page charges. Under postal regulations, this paper therefore must be hereby marked advertisement solely to indicate this fact.
(Criley and Broschat, 1992). Outside the tropical zone, flower production is limited to greenhouse production or the warmer months. In tropical zones, such as in Hawaii, plants will flower outdoors year-round, but in Florida and tropical regions of Australia, production ceases for several months in the winter. Vegetative, and hence flower production, of this cultivar is limited by low temperatures, low incident photosynthetic photon flux (PPF), or both (Broschat and Donselman, 1983). Criley (1989) and Manarangi et al. (1988) found that higher temperatures and higher PPF increased the number of flowers and their production rate. Photoperiod has no apparent effect on growth and flowering of this cultivar (Broschat et al., 1984) or on Heliconia psittacorum 'Tay' (Geertsen, 1989), but other Heliconia species and cultivars respond to photoperiod (Criley and Kawabata, 1986; Geertsen, 1990).

There is a growing interest in cut-flower production from Heliconia under protected cultivation in temperate regions. For the crop to be successful under temperate greenhouse conditions, an understanding of the environmental requirements necessary to produce high-quality flowers (those with strong straight stems and well-formed, well-colored bracts) is needed. Knowledge of the developmental pattern of the plant and the response of development to environmental variables would aid this understanding. Our objectives were to determine the effects of temperature and light on flower development, production, and quality. Shoot growth and flowering responses of the Heliconia cultivar Golden Torch were studied under a combination of two temperatures and two PPF regimes using controlled environmental conditions. The temperatures were chosen to provide a contrast between a tropical growing environment and one that could be attained more realistically in protected growing structures in a temperate growing region.

\section{Materials and Methods}

This study was performed using controlled environment (CE) facilities at the Hort Research National Climate Laboratory, Palmerston North, New Zealand (Dept. of Scientific and Industrial Research Climate Laboratory, 1981). Two-year-old plants of $H$. psittacorum $\times$ H. spathocircinata 'Golden Torch' were obtained from a commercial grower on 21 Jan. 1992. These plants were multiplied by dividing the clumps into sections of at least one rhizome attached to a pseudostem. The sections were immediately potted into 4-liter pots filled with a 1 peat : 1 pumice : 1 gravel (by volume) medium amended with (in g.liter ${ }^{-1}$ ) 3 three-month Osmocote, 6 nine-month Osmocote, $3.3 \mathrm{Si}$ erra Micromax (Grace Sierra, Heerlen, The Netherlands), 8 dolomite lime (Mintech, Auckland, New Zealand), and 3.3 superphosphate (Ravensdown Fertiliser Co-op, Napier, New Zealand) and were placed in a glasshouse under natural long-day $(14 \mathrm{~h})$ photoperiodic conditions. Existing pseudostems were cut back to $5 \mathrm{~cm}$. Plants remained in the glasshouse (air minimum 17C, venting at 27C) for 2 weeks when a total of 90 plants were randomly allocated to four treatments.

Pots were placed on trolleys in two CE rooms for 248 days. There were seven or eight plants per trolley, and six trolleys per room, resulting in a plant density of 22.5 rhizomes/ $\mathrm{m}^{2}$. Each room was lit by four $1000-\mathrm{W}$ highpressure discharge lamps (Metalarc; Sylvania, Drummondville, Que., Canada) and four 1000W quartz halogen lamps (Thorn, Enfield, U.K.) separated from the chamber by a plate glass and water thermal barrier. PPF was 710 $\mu \mathrm{mol} \cdot \mathrm{m}^{-2} \cdot \mathrm{s}^{-1}$ at standard trolley height. The PPF was measured with a quantum sensor (model LI-190S; LI-COR, Lincoln, Neb.). In each room, three of the six trolleys were fitted with neutral-density synthetic screening resulting in a PPF of $475 \mu \mathrm{mol} \cdot \mathrm{m}^{-2} \cdot \mathrm{s}^{-1}$ at standard trolley height. Trolleys were placed in random order in each room, and these trolley positions were changed within each room weekly. Plants were grown under these PPF conditions for $12 \mathrm{~h}$ each day, resulting in daily PPF integrals of 30.7 and $20.5 \mathrm{~mol} \cdot \mathrm{m}^{-2}$. Total daylength was extended to $14 \mathrm{~h}$ with lighting from six 150-W tungsten lamps (Philips, Auckland, New Zealand) for $1 \mathrm{~h}$ immediately 
before and after the main PPF period, to equate with summer daylengths. PPF during daylength extension was $7 \mu \mathrm{mol} \cdot \mathrm{m}^{-2} \cdot \mathrm{s}^{-1}$. Days were at 32 or $24 \pm 0.5 \mathrm{C}$ with nights at $20 \pm 0.5 \mathrm{C}$; vapor pressure deficit was $1.19 \mathrm{kPa}$ at $32 \mathrm{C}$ and 0.75 $\mathrm{kPa}$ at $24 \mathrm{C}$ during the light period and $0.58 \mathrm{kPa}$ during darkness. Carbon dioxide partial pressure levels were monitored but not controlled during the experiment. Pots were irrigated to excess twice daily with half-strength Hoagland's solution (Hoagland and Arnon, 1938).

All shoots were tagged and recorded on emergence. The order of shoot appearance was used in subsequent analyses as a classification variable rather than a treatment variable. At $\approx 4$-day intervals, the number of shoots, leaf stage, and emerged inflorescences were recorded. Leaf stage was recorded as the number of fully expanded leaves plus the fraction of the emerging lamina exposed. This fraction was calculated once the final lamina length of each leaf was known. Inflorescence emergence was recorded at the first appearance of the inflorescence tip through the enclosing leaf sheath. When at least two bracts on an inflorescence had opened, the shoot was harvested by cutting it off at pot level. The following attributes were recorded: number of leaves subtending the inflorescence, total stem length, total inflorescence length, peduncle length exposed above the last fully emerged leaf, peduncle diameter $10 \mathrm{~cm}$ below the basal floral bract, number of floral bracts, and the total number of florets. At the conclusion of the experiment, all fully expanded leaves were removed from the plants, and their areas were measured with a leaf area meter (model 1800; LI-COR). Shoots that had not reached the stage of inflorescence emergence after 248 days were dissected further to determine whether floral initiation had occurred, and if so, how many leaves had been initiated before floral initiation.

General linear models were fitted to the data to assess the influence of environment and plant morphological factors on growth and flower production (SAS Institute, 1990). Individual plants were considered as replicates for each treatment. As plant-plant variation contributed mostly to the experimental error, this procedure appeared to be satisfactory. For the number of leaves subtending the inflorescence, a generalized linear model was fitted with a log-link and Poisson error (SAS Institute, 1993). The influence of each factor on the number of leaves subtending the inflorescence was assessed by the deviance, which was approximately $\chi^{2}$ distributed.

\section{Results}

Shoot and flower production. On average, the first shoot on each plant emerged after 14 days at $32 \mathrm{C}$ day/20C night and after 21 days at 24C day/20C night from the beginning of the treatments. Shoots continued to emerge at varying rates for the duration of the experiment (Fig. 1). Temperature had no significant effect $(P>0.05)$ on the total number of shoots that had emerged by day 248 (data not shown).
However, PPF significantly affected the number of shoots that emerged $(P \leq 0.001)$, with a mean of 10.1 shoots per plant at $710 \mu \mathrm{mol} \cdot \mathrm{m}^{-2} \cdot \mathrm{s}^{-1}$ but only 8.3 per plant at $475 \mu \mathrm{mol} \cdot \mathrm{m}^{-2} \cdot \mathrm{s}^{-1}$. The effect of a lower PPF on shoot emergence was evident after $\approx 60$ days at $32 \mathrm{C}$ day/20C night (Fig. 1) and after $\approx 180$ days at $24 \mathrm{C}$ day/20C night.

The inflorescence of the first shoot emerged

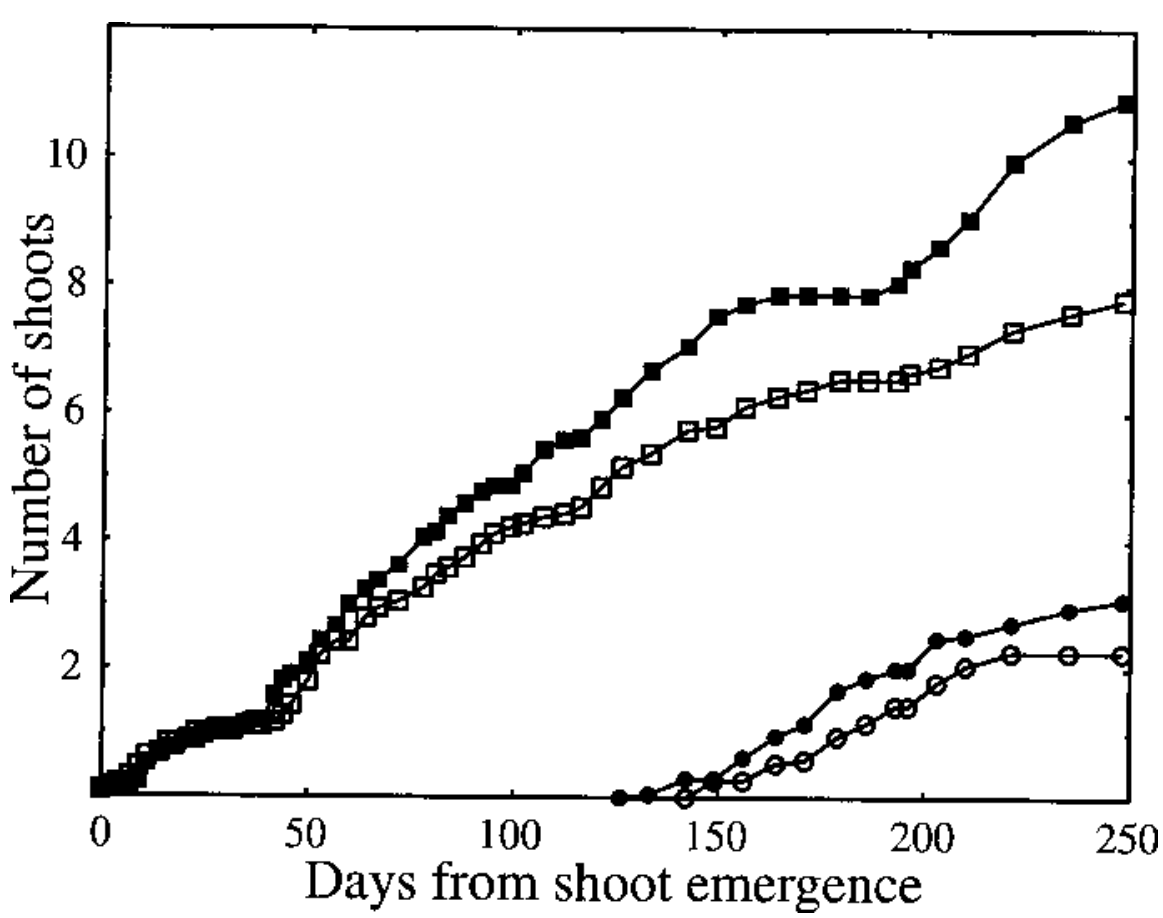

Fig. 1. Shoot and flower production of 'Golden Torch' grown at $32 \mathrm{C}$ day/20C night $[(\square)$ shoots at 475 $\mu \mathrm{mol} \cdot \mathrm{m}^{-2} \cdot \mathrm{s}^{-1}$ photosynthetic photon flux (PPF), (更) shoots at $710 \mu \mathrm{mol} \cdot \mathrm{m}^{-2} \cdot \mathrm{s}^{-1} \mathrm{PPF},(\mathrm{O})$ inflorescences at $475 \mu \mathrm{mol} \cdot \mathrm{m}^{-2} \cdot \mathrm{s}^{-1} \mathrm{PPF},(\boldsymbol{\bullet})$ inflorescences at $\left.710 \mu \mathrm{mol} \cdot \mathrm{m}^{-2} \cdot \mathrm{s}^{-1} \mathrm{PPF}\right]$.

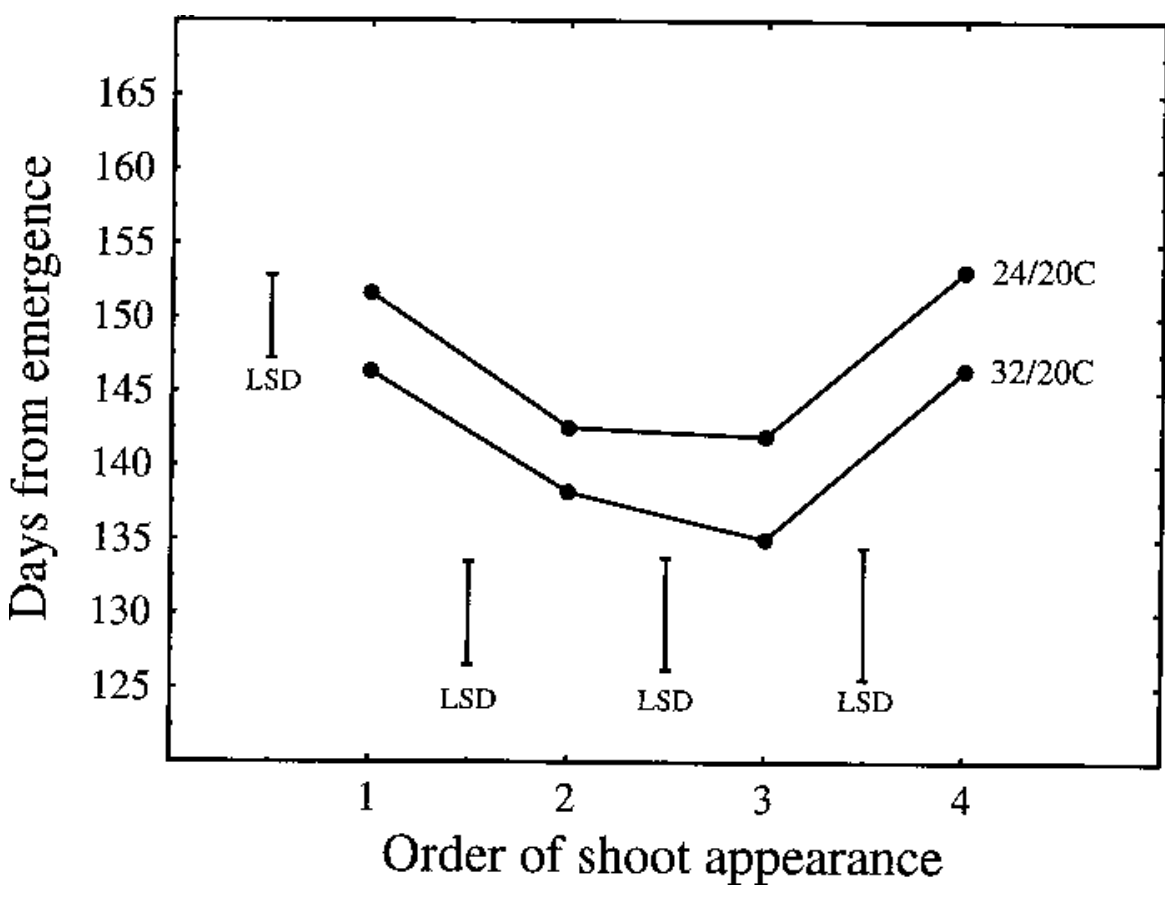

Fig. 2. The effects of order of shoot appearance and temperature on the duration from shoot to inflorescence emergence. The top left least significant difference (LSD) bar corresponds to temperature main effects, and the bottom three LSD bars correspond to shoot order main effects. Photosynthetic photon flux had no significant effect on the duration. 
effects on the proportion of shoots initiating inflorescences, with an average of $85 \%$ of the shoots initiating inflorescences within the 248day treatment period. The main effect of PPF on shoot count, therefore, was reflected directly in total flower yield.

The duration from shoot to inflorescence emergence was shorter at $32 \mathrm{C}$ day/20C night than at 24C day/20C night, despite more leaves being initiated at the higher temperature (Figs. 2 and 3 ). For the first four emerging shoots, the duration averaged 140 days at $32 \mathrm{C}$ day/20C night and 146 days at $24 \mathrm{C}$ day/20C night $(P \leq$ $0.05)$. PPF had no significant effect on this duration, but the duration was strongly influenced by the interacting effects of the order of shoot appearance (Fig. 2) and the number of leaves subtending the inflorescence (Fig. 3 and Tables 1 and 2). The first emerging shoots had the highest number of leaves subtending the inflorescence and typically took the longest to flower. Second and third emerging shoots produced inflorescences most rapidly. Later, emerging shoots took longer to flower, although fewer leaves were produced before flowering commenced on these shoots (Fig. 3 and Table 1). Within an order of shoot appearance, the duration increased with the number of leaves subtending the inflorescence (Table $1)$.

Leaf area at flowering. Temperature and PPF significantly affected the total leaf area per shoot at flowering (Table 3). On average, total leaf area per shoot increased by $19 \%$ at the higher temperature, whereas the lower PPF level increased total leaf area per shoot by an average of $11 \%$. The order of shoot appearance also had a significant effect on the total leaf area per shoot at flowering (Table 3). Total leaf area per shoot generally increased with increasing order of shoot appearance from $0.217 \mathrm{~m}^{2}$ for the first shoot to $0.271 \mathrm{~m}^{2}$ for the fifth shoot to appear. This increase occurred, despite a decrease in the number of leaves subtending the inflorescence, with order of shoot appearance (Fig. 3), as individual leaves on later developing shoots tended to be larger. Leaf area of successive leaves on a shoot increased up to the penultimate leaf (Fig. 4), regardless of treatment, the order of shoot appearance, and the number of leaves subtending the inflorescence. The final leaf was always appreciably smaller than the preceding leaf.

Flower quality. Acceptable flower quality for Heliconia (fancy grade) is defined by the Hawaii Dept. of Agriculture (1972) as welldeveloped (at least two bracts open), clean, well-formed, intact, fresh, firm, and wellcolored flowers. These standards were obtained in all treatments. However, floral attributes were significantly influenced by the environmental factors of temperature, PPF (Table 4), and the order of shoot appearance (Table 5). Flower stem length, stem diameter, flower length, and peduncle length were all significantly greater at the higher temperature. Flower stem length was reduced at the higher PPF level, but stem diameter increased, as did the total number of floral bracts. Flowering stems on the first shoots to emerge were consistently shorter and thinner than those on lateremerging shoots, and their inflorescences were shorter and had fewer floral bracts and florets.

\section{Discussion}

Our plants grew and flowered successfully in each of the temperature and light treatment combinations. Shoot production was higher at

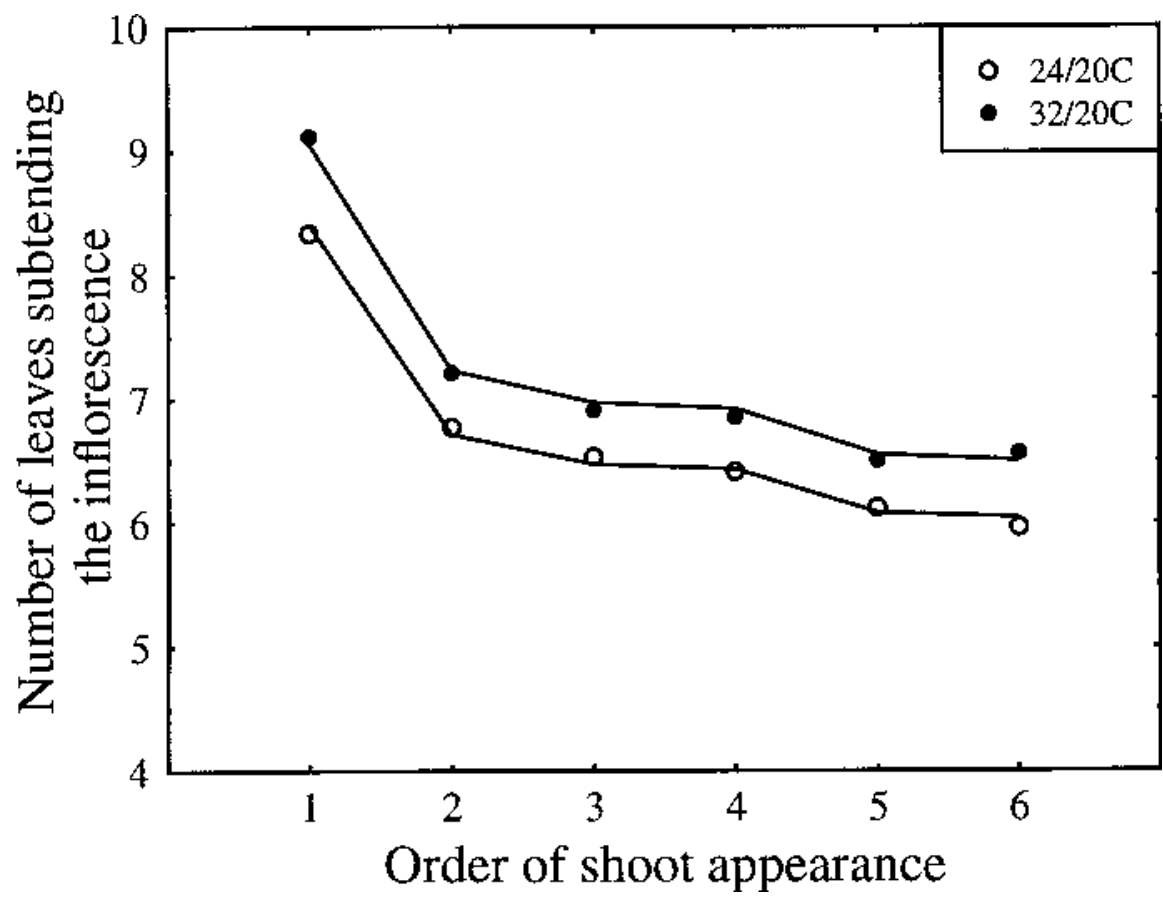

Fig. 3. The effects of order of shoot appearance and of temperature on the mean number of leaves subtending the inflorescence. Lines correspond to the fitted values from the GENMOD procedure, and symbols correspond to the observed means. the higher PPF level but was unaffected by temperature. In contrast, Geersten (1989) found that the rate of shoot production in $H$. psittacorum 'Tay' more than doubled as temperature increased from 15 to $21 \mathrm{C}$, producing a maximum daily rate of 0.85 shoots $/ \mathrm{m}^{2}$ at the higher temperature. This rate is identical to the average rate calculated for the planting density in our study. These results suggest that the temperature optimum for shoot production in 'Golden Torch' is between 22 and 26C.

Although treatments were imposed for only 8 months, an estimate of annual flower production can be made from the observed development pattern. Shoot production was maintained at an approximately constant rate, with an interval of $\approx 27$ days between the emergence of each successive shoot, and flowers were removed $\approx 165$ days after shoot emergence. This sequence suggests that a stable population density of about six shoots per plant would be obtained after 6 months of growth from a single bud rhizome in pot culture. Therefore, each plant could have the potential to produce about 13 flowers per plant annually. Based on a leaf area of 0.25 to 0.30 $\mathrm{m}^{2} /$ mature flowering shoot and a steady state of six developing shoots per plant ranging from newly emerged to mature, a leaf area of $\approx 1 \mathrm{~m}^{2} /$ plant would be attained. Therefore, a population density of only five plants $/ \mathrm{m}^{2}$ would lead to a leaf area index of 5 or greater. Planted at this density in pots, the annual production potential would be $\approx 65$ shoots $/ \mathrm{m}^{2}(\approx 56$ flow$\mathrm{ers} / \mathrm{m}^{2}$ annually), which is less than the 84 reported by Broschat et al. (1984) for production in established outdoor beds in south Florida.

Table 1. Influence of the order of shoot appearance and number of leaves subtending the inflorescence on the duration (days) from shoot to inflorescence emergence. The presence of dashes indicate the absence of shoots with these attributes. Values are least-squares means.

\begin{tabular}{lcccc}
\hline \hline \multirow{2}{*}{$\begin{array}{l}\text { No. leaves } \\
\text { subtending }\end{array}$} & \multicolumn{4}{c}{ Days } \\
\cline { 2 - 5 } inflorescence & \multicolumn{4}{c}{ Order of shoot appearance } \\
\cline { 2 - 5 } & 1 & 2 & 3 & 4 \\
\hline 6 & --- & 131 & 133 & 145 \\
7 & 122 & 141 & 145 & 159 \\
8 & 143 & 168 & 164 & 170 \\
9 & 151 & --- & --- & --- \\
10 & 161 & --- & --- & --- \\
11 & 189 & --- & --- & --- \\
\hline
\end{tabular}

Table 2. Distribution of shoots categorized by order of shoot appearance and the number of leaves subtending the inflorescence for all shoots that initiated flowers by day 248 (all treatments pooled).

\begin{tabular}{lrrrrr}
\hline \hline No. leaves & \multicolumn{5}{c}{ No. shoots } \\
\cline { 2 - 6 } subtending & \multicolumn{5}{c}{ Order of shoot appearance } \\
\cline { 2 - 6 } inflorescence & 1 & 2 & 3 & 4 & 5 \\
\hline 5 & 0 & 0 & 1 & 2 & 6 \\
6 & 1 & 19 & 31 & 30 & 30 \\
7 & 3 & 31 & 25 & 13 & 16 \\
8 & 22 & 8 & 6 & 4 & 4 \\
9 & 23 & 4 & 3 & 0 & 0 \\
10 & 12 & 1 & 1 & 0 & 0 \\
11 & 2 & 0 & 0 & 0 & 0 \\
Mean & 8.8 & 7.0 & 6.7 & 6.6 & 6.3 \\
\hline
\end{tabular}


The observed effect of temperature on the number of leaves subtending the inflorescence is in agreement with results obtained by Geertsen (1990) with $H$. aurantiaca. In this species, the number of leaves subtending the inflorescence increased by an average of 2.5 leaves when temperature was $21 \mathrm{C}$ rather than 15C. Photoperiod has no apparent effect on growth and flowering of 'Golden Torch' (Broschat and Donselman, 1983; Criley, 1989), and four or five leaves normally subtend the inflorescence in naturally changing photoperiod environments (Broschat et al., 1984). Plants in our study were grown under constant 14-h photoperiods, and we expected that all shoots would have had a similar number of leaves subtending the inflorescence. The steady decline in the number of leaves subtending the inflorescence with increasing order of appearance of shoots was, therefore, an unexpected result in our study. The decline in leaf count was not accounted for by an equivalent increase in the number of leafless bracts emerging before the first true leaf. Bract counts increased from an average of 1.4 per shoot for the first emerged shoots to an average of 1.9 for the sixth shoots. Several hypotheses can be put forward to explain the decline in the number of leaves. The high number of leaves subtending the inflorescence for the first emerging shoots may have been the result of some form of rejuvenation induced by rhizome propagation, with the effect dissipating slowly over time. Alternatively, inadequate carbohydrate supply in the initial propagule may have delayed flower initiation, resulting in additional leaves being initiated during this delay; Robinson and Nel (1988) have suggested that this may be the case in the closely related species Musa. Third, as each shoot grows into a successively more self-shaded environment, the altering red : far red ratio of this microenvironment may influence the rate of floral initiation. Davis and Simmons (1994) suggest that such self-shading effects may be responsible for the lower number of leaves subtending the inflorescence on tillers of barley (Hordeum vulgare L.) compared with the main stem.

A practical consequence of the declining number of leaves subtending the inflorescence is that the duration from shoot to inflorescence emergence is not constant for successive shoots. This duration ranged from 20 to 23 weeks in our study, in contrast to Broschat et al. (1984), who reported that a harvestable inflorescence for 'Golden Torch' was produced 9 to 10 weeks after shoot emergence in a typical south Florida summer, and Manarangi et al. (1988), who reported a duration of 16 to 18 weeks in the field at Hawaii. In our study, the duration from shoot to inflorescence emergence was longer at the lower temperature but also was influenced by the order of shoot appearance and the number of leaves subtending the inflorescence. The increase in duration for lateremerging shoots, despite a reduction in number of leaves subtending the inflorescence, implies that the apparent rate of leaf appearance declines with increasing order of shoot appearance. Allen et al. (1988) found a similar
Table 3. Effect of temperature and photosynthetic photon flux (PPF) on total leaf area per shoot at flowering (square meter per shoot). Values are least-squares means.

\begin{tabular}{|c|c|c|c|c|c|}
\hline \multirow[b]{4}{*}{ Shoot } & \multicolumn{5}{|c|}{ Leaf area $\left(\mathrm{m}^{2} / \mathrm{shoot}\right)$} \\
\hline & \multicolumn{4}{|c|}{ Treatment factors } & \multirow[b]{3}{*}{ Pooled } \\
\hline & \multicolumn{2}{|c|}{ Temp $\left({ }^{\circ} \mathrm{C}\right)$} & \multicolumn{2}{|c|}{$\mathrm{PPF}\left(\mu \mathrm{mol} \cdot \mathrm{m}^{-2} \cdot \mathrm{s}^{-1}\right)$} & \\
\hline & $24 / 20$ & $32 / 20$ & 475 & 710 & \\
\hline 1 & $0.195^{* *}$ & 0.242 & $0.228^{* * *}$ & 0.207 & $\overline{0.217 \mathrm{~A}}$ \\
\hline 2 & $0.226^{* *}$ & 0.256 & $0.249^{\mathrm{Ns}}$ & 0.233 & $0.240 \mathrm{~B}$ \\
\hline 3 & $0.217^{* *}$ & 0.261 & $0.246^{\mathrm{NS}}$ & 0.230 & $0.238 \mathrm{~B}$ \\
\hline 4 & $0.243^{* *}$ & 0.280 & $0.277^{* *}$ & 0.245 & $0.260 \mathrm{C}$ \\
\hline 5 & $0.249^{* *}$ & 0.302 & $0.295^{*}$ & 0.255 & $0.271 \mathrm{C}$ \\
\hline
\end{tabular}

${ }^{2}$ Mean separation in column by pairwise comparison using a $t$ test at $P=0.01$ (uppercase letters).

ws, ${ }^{*}, * *$ Nonsignificant or significant at $P=0.05$ or 0.01 , respectively, when comparing within a treatment factor at the shoot level.

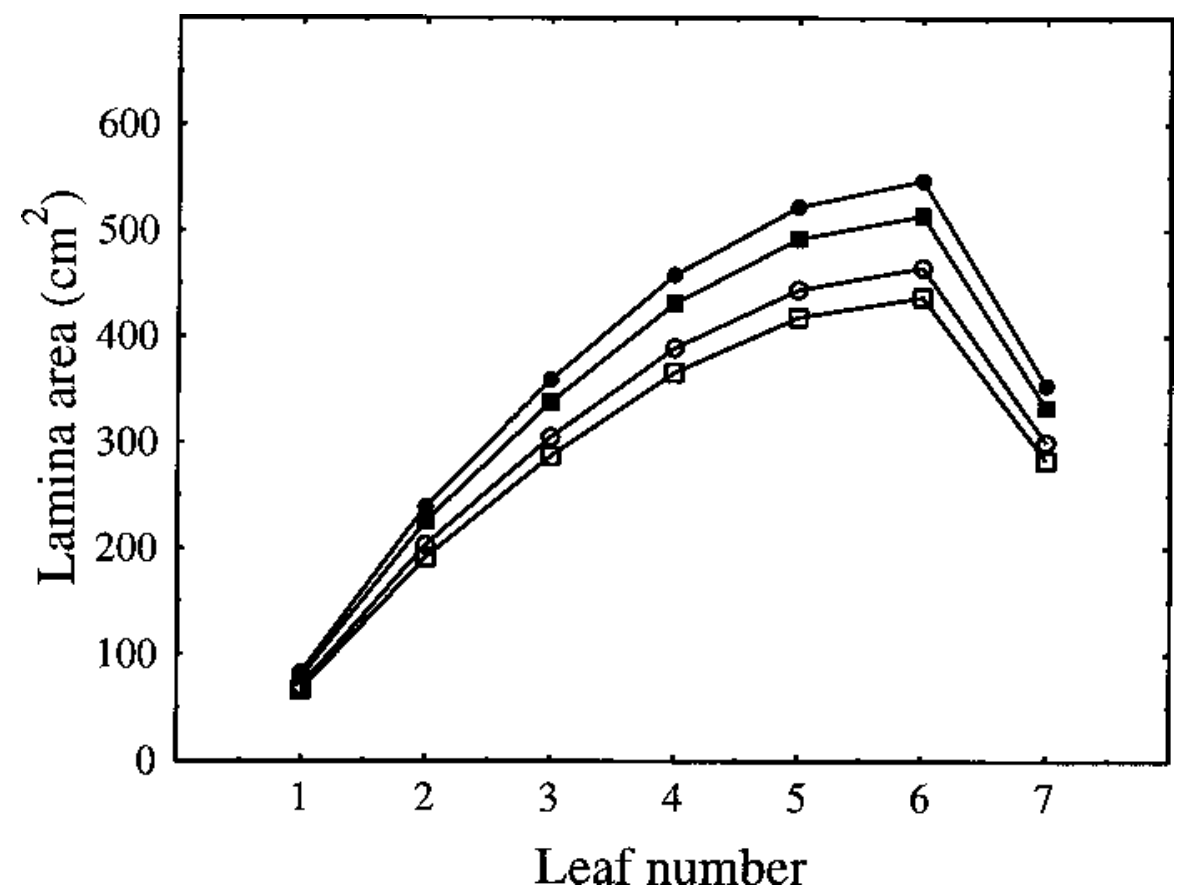

Fig. 4. The effects of temperature and photosynthetic photon flux (PPF) on individual leaf areas for thirdorder shoots flowering with seven leaves [(]) $24 \mathrm{C}$ day $/ 20 \mathrm{C}$ night, $710 \mu \mathrm{mol} \cdot \mathrm{m}^{-2} \cdot \mathrm{s}^{-1} \mathrm{PPF}$; (O) $24 \mathrm{C}$ day/ $20 \mathrm{C}$ night, $475 \mu \mathrm{mol} \cdot \mathrm{m}^{-2} \cdot \mathrm{s}^{-1} \mathrm{PPF}$; (ם) 32C day $/ 20 \mathrm{C}$ night, $710 \mu \mathrm{mol} \cdot \mathrm{m}^{-2} \cdot \mathrm{s}^{-1} \mathrm{PPF} ;(\mathbf{\bullet}) 32 \mathrm{Cday} / 20 \mathrm{Cnight}$, $\left.475 \mu \mathrm{mol} \cdot \mathrm{m}^{-2} \cdot \mathrm{s}^{-1} \mathrm{PPF}\right]$.

Table 4. Effect of temperature and photosynthetic photon flux (PPF) on flower quality attributes measured at harvest. Values are least-squares means.

\begin{tabular}{|c|c|c|c|c|}
\hline \multirow[b]{3}{*}{ Attribute } & \multicolumn{4}{|c|}{ Treatment factors } \\
\hline & \multicolumn{2}{|c|}{ Temp $\left({ }^{\circ} \mathrm{C}\right)$} & \multicolumn{2}{|c|}{$\mathrm{PPF}\left(\mu \mathrm{mol} \cdot \mathrm{m}^{-2} \cdot \mathrm{s}^{-1}\right)$} \\
\hline & $24 / 20$ & $32 / 20$ & 475 & 710 \\
\hline Flower stem length $(\mathrm{cm})$ & $138.8^{* *}$ & 150.1 & $148.1^{*}$ & 140.8 \\
\hline Peduncle length $(\mathrm{cm})$ & $28.5^{*}$ & 34.4 & $33.2^{\mathrm{NS}}$ & 29.8 \\
\hline Flower length $(\mathrm{cm})$ & $16.2^{*}$ & 17.0 & $16.5^{\mathrm{NS}}$ & 16.7 \\
\hline Total number of floral bracts & $5.0^{\mathrm{NS}}$ & 5.3 & $5.0^{*}$ & 5.3 \\
\hline Total number of florets & $17.8^{\mathrm{NS}}$ & 18.9 & $17.9^{\mathrm{NS}}$ & 18.8 \\
\hline Stem diameter $(\mathrm{mm})$ & $5.37^{* *}$ & 5.81 & $5.42^{* *}$ & 5.76 \\
\hline
\end{tabular}

Ns, ${ }^{, * *}$ Nonsignificant or significant at $P=0.05$ or 0.01 , respectively, when comparing within a treatment factor.

Table 5. Influence of the order of shoot appearance on flower quality attributes measured at harvest. Values are least-squares means.

\begin{tabular}{lcccc}
\hline \hline & \multicolumn{4}{c}{ Shoot } \\
\cline { 2 - 5 } Attribute & 1 & 2 & 3 & 4 \\
\hline Flower stem length $(\mathrm{cm})^{\mathrm{z}}$ & $130 \mathrm{a}$ & $141 \mathrm{~b}$ & $151 \mathrm{bc}$ & $156 \mathrm{c}$ \\
Peduncle length $(\mathrm{cm})$ & $32.4^{\text {ss }}$ & 28.3 & 32.8 & 32.4 \\
Flower length $(\mathrm{cm})$ & $15.9 \mathrm{a}$ & $16.7 \mathrm{ab}$ & $16.6 \mathrm{ab}$ & $17.0 \mathrm{~b}$ \\
Total number of floral bracts & $4.7 \mathrm{a}$ & $5.3 \mathrm{~b}$ & $5.3 \mathrm{~b}$ & $5.4 \mathrm{~b}$ \\
Total number of florets & $16.0 \mathrm{a}$ & $18.0 \mathrm{ab}$ & $19.3 \mathrm{~b}$ & $22.4 \mathrm{~b}$ \\
Stem diameter $(\mathrm{mm})$ & $5.32 \mathrm{a}$ & $5.63 \mathrm{~b}$ & $5.67 \mathrm{~b}$ & $5.74 \mathrm{~b}$ \\
\hline
\end{tabular}

${ }^{2}$ Mean separation in rows by pairwise comparison using a $t$ test at $P=0.05$. 
age-related effect on leaf emergence rate in Musa.

Research focus on Heliconia has tended to be production-oriented rather than detailing desirable quality characteristics, so it is difficult to quantify flower quality. Many of the standards set by the Hawaii Dept. of Agriculture (1972) relate to downgrading due to disease and physical injury and do not define acceptable bract or floret counts or dimensions. However, the department's flower quality standards require at least two, opened, well-formed, well-colored bracts, and based on these standards, flower production and flower quality was acceptable in the four environments imposed in our study. Thus, flower production of 'Golden Torch' should be feasible in temperature-controlled greenhouses in temperate regions providing mean temperatures of $\approx 20 \mathrm{C}$ can be maintained. Geertsen (1989) reached a similar conclusion regarding the growth of $H$. psittacorum 'Tay' under glass in Denmark. Van Raalte and van RaalteWichers (1973) also suggested that mean temperatures for $H$. psittacorum should not drop to $<21 \mathrm{C}$. Further work will be required to ascertain if minimum PPF levels are required to sustain economic, year-round, high-quality production of this crop in temperate midlatitude regions.

\section{Literature Cited}

Allen, R.N., E.B. Dettmann, G.G. Johns, and D.W Turner. 1988. Estimation of leaf emergence rates of bananas. Austral. J. Agr. Res. 39:53-62.

Berry, F. and W.J. Kress. 1991. Heliconia: An identification guide. 1st ed. Smithsonian Inst. Press, Washington, D.C.

Broschat, T.K. and H.M. Donselman. 1983. Production and postharvest culture of Heliconia psittacorum flowers in south Florida. Proc. Fla. State Hort. Soc. 96:272-273.

Broschat, T.K., H.M. Donselman, and A.A. Will. 1984. 'Andromeda' and 'Golden Torch' heliconias. HortScience 19:736-737.

Criley, R.A. 1989. Development of Heliconia and Alpinia in Hawaii: Cultivar selection and culture. Acta Hort. 246:247-258.

Criley, R.A. and T.K. Broschat. 1992. Heliconia: Botany and horticulture of a new floral crop. Hort. Rev. 14:1-55.

Criley, R.A. and O. Kawabata. 1986. Evidence for a short-day flowering response in Heliconia stricta 'Dwarf Jamaican'. HortScience 21:506507

Davis, M.H. and S.R. Simmons. 1994. Far-red light reflected from neighbouring vegetation promotes shoot elongation and accelerates flowering in spring barley plants. Plant Cell Environ. 17:829836.

Department of Scientific and Industrial Research Climate Laboratory. 1981. DSIR Extension Information, Alpha 14, Wellington, New Zealand.
Geertsen, V. 1989. Effect of photoperiod and temperature on the growth and flower production of Heliconia psittacorum 'Tay'. Acta Hort. 252:117-122.

Geertsen, V. 1990. Influence of photoperiod and temperature on the growth and flowering of Heliconia aurantiaca. HortScience 25:646648.

Hawaii Department of Agriculture. 1972. Regulation no. 2 , title 4 , subtitle 4 , chapter 42 , Standards for Hawaii-grown flowers and foliage. subchapter 2. Standards for grades of flowers and foliage. Hawaii Dept. of Agriculture, Honolulu.

Hoagland, D.R. and D.I. Arnon. 1938. The waterculture method for growing plants without soil. Univ. of California Agr. Expt. Sta. Circ. 437.

Manarangi, A., W.S. Sakai, C. Gerken, M. Crowell, G. Nielson, and R. Short. 1988. Growth and flowering of Heliconia psittacorum cv. Parrot. Hawaii J. Hawaii Pacific Agr. 1:1-3.

Robinson, J.C. and D.J. Nel. 1988. Plant density studies with banana (cv. Williams) in a subtropical climate. I. Vegetative morphology, phenology and plantation microclimate. J. Hort. Sci. 63:303-313.

SAS Institute. 1990. SAS/STAT user's guide. Version 6. 4th ed. SAS Inst., Cary, N.C.

SAS Institute. 1993. SAS technical report P-243, SAS/STAT software: The GENMOD procedure release 6.09. SAS Inst., Cary, N.C.

van Raalte, D. and D. van Raalte-Wichers. 1973. Heliconia. Vakblad Bloem 28:12-13. 